\title{
EFEKTIFITAS TEKNIK RELAKSASI PROGRESIF UNTUK MENGURANGI INSOMNIA PADA USIA LANJUT
}

\author{
Effectiveness Of Progressive Relaxation Techniques To Reduce \\ Insomnia In Elderly \\ Ganik Sakitri ${ }^{1}$, Ratna Kusuma Astuti ${ }^{2}$ \\ AKPER Insan Husada Surakarta \\ (ganiksakitri2312@gmail.com)
}

\begin{abstract}
ABSTRAK
Latar Belakang : Tidur merupakan kebutuhan manusia yang teratur. Akan tetapi, sekitar $65 \%$ usia lanjut mengalami insomnia. Insomnia pada usia lanjut dapat diatasi dengan cara non medikasi, salah satunya dengan tehnik relaksasi progresif. Tujuan : Penelitian ini bertujuan untuk mengetahui efektifitas tehnik relaksasi progresif untuk mengurangi insomnia pada usia lanjut di Posyandu usia lanjut desa Buntalan.

Metode : Jenis penelitian ini adalah quasi eksperimen dengan two group pretest and postest. Populasi dalam penelitian ini adalah usia lanjut yang mengikuti kegiatan posyandu lansia di desa buntalan. Tehnik pengambilan sampel menggunakan total populasi dengan jumlah responden sebanyak 30 orang dan terbagi menjadi 2 kelompok. Kelompok A dilakukan tehnik relaksasi progresif setiap hari dan kelompok B dilakukan tehnik relaksasi progresif 3 kali seminggu. Pengumpulan data yang dilakukan pada saat sebelum dan sesudah dilakukan tehnik relaksasi progresif dengan menggunakan Insomnia Rating Scale. Analisa data statistik menggunakan uji Chi Square

Hasil : Tehnik relaksasi progresif yang dilakukan setiap hari efektif untuk mengurangi insomnia pada usia lanjut. Hal ini dapat dilihat dari penurunan jumlah responden yang mengalami insomnia, pada kelompok sebanyak 23,08 \% dan kelompok B sebanyak $61,54 \%$. Hasil uji statistik menunjukkan nilai $\chi 2$ hitung $=$ 2,521 sedangkan harga $\chi 2$ tabel $=3,841$ pada derajat kebebasan $(\mathrm{df}) 1$, pada taraf signifikansi 0,05 maka Ho diterima artinya tehnik relaksasi progresif efektif untuk mengurangi insomnia pada usia lanjut di Posyandu usia lanjut desa Buntalan.
\end{abstract}

Simpulan: Tehnik relaksasi progresif tidak efektif untuk mengurangi insomnia pada usia lanjut di Posyandu usia lanjut desa Buntalan.

Kata kunci: Usia lanjut, insomnia, teknik relaksasi progresif.

\section{ABSTRACT}

Background: Sleep is a regular human need. However, about $65 \%$ of the elderly people experience insomnia. Insomnia in the elderly can be overcome by nonmedication, one of them is with progressive relaxation techniques.

Objective: This study aims to determine the effectiveness of progressive relaxation techniques to reduce insomnia in the elderly at Posyandu Lansia Buntalan village. 
Method: This type of research is a quasi-experimental with two groups pretest and posttest. The population in this study was the elderly who participated in Posyandu Lansia Buntalan village. The sampling technique uses a total population of 30 respondents and is divided into 2 groups. Group A performed progressive relaxation techniques every day and group $B$ performed progressive relaxation techniques 3 times a week. Data collection was carried out before and after progressive relaxation techniques were carried out using the Insomnia Rating Scale. Analysis of statistical data using Chi Square test.

Results: Progressive relaxation techniques performed every day are effective for reducing insomnia in the elderly. This can be seen from the decrease in the number of respondents experiencing insomnia, in the group of $23.08 \%$ and group $B$ of $61.54 \%$. Statistical test results show the value of $\chi^{2}$ count $=2.521$ while the price of $\chi^{2}$ table $=3.841$ at $(d f) 1$, at a significance level of 0.05 then Ho is accepted, meaning that progressive relaxation techniques are effective in reducing insomnia in the elderly at Posyandu Lansia Buntalan village.

Conclusion: Progressive relaxation techniques are not effective for reducing insomnia in the elderly at Posyandu Lansia Buntalan village.

Keywords: elderly, insomnia, progressive relaxation techniques.

\section{PENDAHULUAN}

. Tidur merupakan bagian hidup manusia yang memiliki porsi banyak, ratarata hampir seperempat hingga sepertiga waktu digunakan untuk tidur. Tidur merupakan kebutuhan bukan suatu keadaan istirahat yang tidak bermanfaat. Tidur merupakan proses yang diperlukan oleh manusia untuk pembentukan sel-sel tubuh yang baru, perbaikan sel-sel tubuh yang rusak (natural healing mechanism), memberi waktu organ tubuh untuk beristirahat maupun untuk menjaga keseimbangan metabolisme dan biokimiawi tubuh (Mass, 2012).

Lebih dari $80 \%$ penduduk usia lanjut menderita penyakit fisik yang mengganggu fungsi mandirinya. Sejumlah $30 \%$ pasien yang menderita sakit fisik tersebut menderita kondisi komorbid psikiatrik, terutama depresi dan kecemasan. Sebagian besar usia lanjut yang menderita depresi dan gangguan mental tersebut mengalami gangguan tidur (Prayitno, 2002).

Menurut Staab \& Hodges (1996) gangguan tidur cenderung meningkat setiap dekade dan mempengaruhi lebih dari sepertiga usia lanjut yang berusia lebih dari 75 tahun. Semakin bertambahnya usia terdapat penurunan dari periode tidur. Kebutuhan tidur akan berkurang dari usia bayi sampai usia lanjut. Bayi yang baru lahir tidur rata-rata 20 jam sehari, anak berusia 6 tahun rata-rata 10 jam, anak umur 12 tahun tidur rata-rata 9 jam, sedangkan orang dewasa 7 jam 20 menit. Orang yang berusia lebih dari 60 tahun sering menyampaikan keluhan gangguan tidur, terutama masalah kurang tidur. Perubahan pola tidur ini adalah umum, dan merupakan bagian alamiah dari penuaan. Gangguan pola tidur pada kelompok usia lanjut cukup tinggi. Pada usia lebih dari 65 tahun, mereka yang tinggal di rumah, setengahnya diperkirakan mengalami gangguan tidur dan dua pertiga yang 
tinggal di tempat perawatan usia lanjut juga mengalami gangguan pola tidur (Prayitno, 2002).

Dalam suatu penelitian, subyek menunjukkan penurunan jumlah waktu tidur (tahap 3 dan 4) yang dimulai sekitar akhir usia 40 dan usia 50 tahun, serta mengalami persentase tidur stadium I yang lebih tinggi. Tidur Rapid Eye Movement (REM) dipertahankan dengan baik pada proses menua, walaupun jumlah absolutnya menurun sebagai fungsi dari penurunan waktu tidur total. Efikasi tidur (rasio waktu tertidur dibandingkan dengan waktu total berbaring di tempat tidur) menurun dari $95 \%$ pada dewasa muda hingga kurang dari $75 \%$ pada usia lanjut (Abrams \& Berkow, 1997).

Kesulitan tidur atau insomnia adalah keluhan tentang kurangnya kualitas tidur antara lain sulit memasuki tidur, sering terbangun malam kemudian kesulitan untuk kembali tidur, bangun terlalu pagi, dan tidur yang tidak nyenyak. Insomnia tidak disebabkan oleh sedikitnya waktu seseorang tidur, karena setiap orang memiliki jumlah jam tidur sendiri-sendiri (Edinger, 2000). Berbagai penelitian menunjukkan bahwa gangguan tidur merupakan masalah penting pada usia lanjut. Gangguan tidur menyebabkan timbulnya gangguan kognisi, gangguan kinerja motorik, dan perasaan malaise, serta malas juga sering ditemukan (Abrams \& Berkow, 1997).

Insomnia merupakan gangguan tidur yang paling sering ditemukan. Setiap tahun diperkirakan sekitar 20\% - 50\% orang dewasa melaporkan adanya gangguan tidur dan sekitar $17 \%$ mengalami gangguan tidur yang serius. Prevalensi gangguan tidur pada usia lanjut cukup tinggi yaitu sekitar 67\% (Nurmiati, 2007). Sebuah penelitian yang dilakukan oleh Liu di Jepang disebutkan $29 \%$ responden tidur kurang dari 6 jam, $23 \%$ merasa kekurangan dalam jam tidur, 6\% menggunakan obat tidur, $15 \%$ kondisi mengantuk yang parah pada siang harinya, kemudian 21\% memiliki prevalensi insomnia (Liu, 2000). Prevalensi insomnia pada usia lanjut di Indonesia berkisar 10 persen. Dengan kata lain, kurang lebih 28 juta dari total 238 juta penduduk Indonesia menderita insomnia. Sedangkan hasil survey yang dilakukan oleh Dian di Yogyakarta menunjukkan bahwa 53\% dari total populasi usia lanjut menyatakan keluhan insomnia (Murti, 2004).

Ada beberapa dampak serius gangguan tidur pada lansia misalnya mengantuk berlebihan di siang hari, gangguan atensi dan memori, mood depresi, sering terjatuh, penggunaan hipnotik yang tidak semestinya, dan penurunan kualitas hidup. Angka kematian, angka sakit jantung dan kanker lebih tinggi pada seseorang yang lama tidurnya lebih dari 9 jam atau kurang dari 6 jam per hari bila dibandingkan dengan seseorang yang lama tidurnya antara 7 - 8 jam per hari (Nurmiati, 2007).

Penyembuhan terhadap insomnia tergantung dari penyebab yang menimbulkan insomnia. Bila penyebabnya adalah kebiasaan yang salah atau lingkungan yang kurang kondusif untuk tidur maka terapi yang dilakukan adalah mengubah kebiasaan dan lingkungannya. Sedangkan untuk penyebab psikologis terapi relaksasi dapat digunakan untuk mengurangi gangguan sulit tidur, terapi ini merupakan bentuk terapi psikologis yang mendasarkan pada teori-teori behavioris (Purwanto \& Zulaekha, 2007). Dalam literatur psikologi salah satu terapi perilaku 
(behavior therapy) adalah terapi relaksasi. Salah satu bentuk terapi relaksasi adalah relaksasi progresif yang banyak digunakan untuk penurunan ketegangan, atau mencapai kondisi tenang. Jacobson \& Wolpe dalam penelitiannya menunjukkan bahwa tehnik relaksasi progresif dapat mengurangi ketegangan dan kecemasan (Keliat, 1999).

Berdasarkan hasil survei awal di Posyandu usia lanjut desa Buntalan yang telah dilakukan pada bulan November - Desember 2018, peneliti memperoleh data usia lanjut yang aktif dalam Posyandu usia lanjut berjumlah 63 orang, dengan kisaran umur antara 55 - 70 tahun. Data yang didapatkan dari hasil wawancara menunjukkan bahwa sekitar 41 orang menyatakan keluhan gangguan tidur atau sekitar $65 \%$ dari total populasi. Gangguan tidur yang dialami oleh usia lanjut disebabkan oleh keluhan-keluhan seperti nyeri sendi terutama bagian kaki, nyeri kepala, nyeri badan, kecemasan, dan beban pikiran. Sikap usia lanjut dalam menghadapi gangguan tidur ini berbeda-beda. Ada yang menanggapinya dengan sikap positif seperti menerima keadaannya karena memang sudah tua, lebih mendekatkan diri pada Tuhan dengan berdoa jika tidak bisa tidur atau pada saat terbangun malam hari, melakukan aktifitas tertentu (makan, nonton TV) jika tidak bisa tidur. Ada juga yang menanggapinya dengan sikap negatif seperti cemas terhadap keadaannya tetapi tidak sampai mengkonsumsi obat tidur, ada juga yang tidak memperdulikan masalah dan cenderung membiarkan masalah.

\section{METODE PENELITIAN}

Desain penelitian ini menggunakan jenis penelitian eksperimen semu (quasi eksperiment) dengan Two Group Pretest dan Postest karena peneliti ingin mengetahui seberapa efektif relaksasi progresif yang dilakukan pada kedua kelompok. Kelompok A adalah responden yang dilakukan relaksasi progresif setiap hari dan kelompok B yang dilakukan relaksasi progresif 3 kali seminggu.

Populasi dalam penelitian ini adalah semua usia lanjut yang mengalami insomnia dan menjadi anggota Posyandu usia lanjut di desa Buntalan. Populasi berjumlah 30 orang. Pengambilan sampel dengan teknik total populasi.

Alat pengumpulan data menggunakan instrument Insomnia Rating Scale untuk mengetahui tingkat insomnia yang dikembangkan oleh Kelompok Studi Psikitari Biologik Jakarta (KSPBJ). Insomnia Rating Scale telah dilakukan uji validitas isi (Content Validity). Instrumen ini telah teruji reliabilitasnya dengan hasil yang tinggi, baik psikiater dengan psikiater $(r=0,95)$ maupun antar psikiater dengan dokter non psikiater $(r=0,94)$. Uji sensitifitas alat ini cukup tinggi yaitu 97,4\% dan spesifitas sebesar $87,5 \%$. Instrumen yang digunakan untuk intervensi relaksasi progresif menggunakan pedoman prosedur Tindakan Relaksasi Progresif. 


\section{HASIL DAN PEMBAHASAN}

Hasil penelitian dapat dilihat sebagai berikut:

1. Umur Responden

Tabel 1 Distribusi Frekuensi karakteristik Umur Responden

\begin{tabular}{ccc}
\hline Umur & Frekuensi & $\%$ \\
\hline $55-60$ tahun & 10 & 33,33 \\
$61-70$ tahun & 20 & 66,67 \\
Total & 30 & 100 \\
\hline
\end{tabular}

Tabel diatas menunjukkan umur usia lanjut yang berusia 55 - 60 tahun sebanyak 10 responden $(33,33 \%)$ dan $61-70$ tahun 20 responden $(66,67 \%)$.

2. Jenis Kelamin

Tabel 2 Distribusi Frekuensi karakteristik jenis kelamin responden

\begin{tabular}{ccc}
\hline Jenis kelamin & Frekuensi & $\%$ \\
\hline Laki-laki & 12 & 40 \\
Wanita & 18 & 60 \\
Total & 30 & 100 \\
\hline
\end{tabular}

Tabel diatas menunjukkan bahwa jumlah wanita yang mengalami insomnia lebih banyak dari pada laki-laki yaitu 18 responden (60\%) dan laki-laki 12 responden $(40 \%)$.

3. Status Perkawinan

Tabel 3 Distribusi Frekuensi karakteristik status perkawinan responden

\begin{tabular}{ccc}
\hline Status perkawinan & Frekuensi & $\%$ \\
\hline Menikah & 19 & 63,33 \\
Janda & 7 & 23,33 \\
Duda & 3 & 10 \\
Tidak menikah & 1 & 3,3 \\
Total & 30 & 100 \\
\hline
\end{tabular}

Untuk status perkawinan yang paling banyak adalah status menikah 19 responden $(63,33 \%)$, janda 7 responden $(23,33 \%)$, duda 3 responden $(10 \%)$, dan tidak menikah 1 responden $(3,3 \%)$.

4. Tingkat Pendidikan

Tabel 4 Distribusi Frekuensi Karakteristik Tingkat Pendidikan Responden

\begin{tabular}{ccc}
\hline Tingkat pendidikan & Frekuensi & $\%$ \\
\hline Tidak sekolah & 5 & 16,67 \\
SD & 17 & 56,67 \\
SLTP & 3 & 10 \\
SLTA & 5 & 16,67 \\
Total & 30 & 100 \\
\hline
\end{tabular}


Pendidikan paling banyak adalah SD 17 orang (56,67\%), kemudian tidak sekolah dan SLTA 5 orang (16,67\%), SLTP sebanyak 3 orang (10\%).

5. Hasil Pengujian

Berdasarkan hasil penelitian di Posyandu usia lanjut desa Buntalan terhadap 30 usia lanjut yang mengalami insomnia dan dikelompokkan menjadi 2 dengan masing-masing kelompok beranggotakan 15 orang. Kemudian diperoleh data insomnia dan tidak insomnia pada kelompok yang dilakukan tehnik relaksasi progresif setiap hari dan 3 kali seminggu seperti dibawah ini.

Tabel 5 Distribusi Frekuensi Insomnia Dengan Relaksasi Progresif Setiap Hari

\begin{tabular}{ccc}
\hline Kelompok & Frekuensi & $\%$ \\
\hline Insomnia & 5 & 33,33 \\
Tidak insomnia & 10 & 66,67 \\
Total & 15 & 100 \\
\hline
\end{tabular}

Tabel diatas menunjukkan bahwa usia lanjut yang melakukan relaksasi progresif setiap hari yang mengalami insomnia sebanyak 5 orang $(33,33 \%)$ dan tidak insomnia 10 orang $(66,67 \%)$.

Tabel 6 Distribusi Frekuensi Insomnia Dengan Relaksasi 3 Kali Seminggu

\begin{tabular}{ccc}
\hline Kelompok & Frekuensi & $\%$ \\
\hline Insomnia & 9 & 60 \\
Tidak insomnia & 6 & 40 \\
Total & 15 & 100 \\
\hline
\end{tabular}

Tabel diatas menunjukkan bahwa usia lanjut yang melakukan relaksasi progresif 3 kali seminggu yang mengalami insomnia sebanyak 9 orang $(60 \%)$ dan tidak insomnia sebanyak 6 orang $(40 \%)$.

Tabel 7 Cross Tabulation terapi relakasasi progresif dengan insomnia di Posyandu Usia Lanjut Desa Buntalan

\begin{tabular}{|c|c|c|c|c|c|}
\hline \multirow[t]{2}{*}{ Kelompok } & \multicolumn{2}{|c|}{ Latihan relaksasi progresif } & \multirow[t]{2}{*}{ Total } & \multirow[t]{2}{*}{$P_{\text {value }}$} & \multirow[t]{2}{*}{$\chi^{2}$} \\
\hline & $\begin{array}{l}\text { Kelompok A } \\
\text { (Setiap hari) }\end{array}$ & $\begin{array}{c}\text { Kelompok B } \\
\text { (3 kali semiggu) }\end{array}$ & & & \\
\hline Tidak insomnia & 10 & 6 & 16 & 0,112 & 2,521 \\
\hline insomnia & 5 & 9 & 14 & & \\
\hline Total & 15 & 15 & 30 & & \\
\hline
\end{tabular}

Setelah diketahui hasil dari tabel cross tabulation terapi relaksasi progresif dengan insomnia, kemudian data dianalisis dengan uji Chi Square. Berdasarkan hasil perhitungan $C h i$ square diperoleh nilai $\chi^{2}$ hitung $=2,521$ sedangkan harga $\chi^{2}$ tabel $=3,841$ pada derajat kebebasan $(\mathrm{df}) 1$, pada taraf signifikansi 0,05 . Hal ini berarti bahwa $\chi^{2}$ hitung $<\chi^{2}$ tabel maka dapat disimpulkan bahwa tehnik relaksasi progresif efektif untuk mengurangi insomnia pada usia lanjut, jadi hipotesis alternatif ditolak dan hipotesis nol diterima. Hasil penelitian menunjukkan nilai Asymp. Sig. yaitu $p=0,112(\mathrm{p}>0,05)$ yang berarti tehnik relaksasi progresif tidak 
fektif untuk mengurangi insomnia pada usia lanjut di Posyandu usia lanjut desa Buntalan.

Pada penelitian ini didapatkan responden yang didapat lebih banyak wanita. Wanita lebih bersifat emosional dalam menghadapi masalah dan faktor emosional itu menyebabkan usia lanjut mengalami insomnia. Menurut Abrams \& Berkow (1997) insomnia lebih banyak mempengaruhi wanita pascamenopause dibandingkan laki-laki. Insomnia merupakan salah satu gejala psikologis yang paling menonjol pada wanita pascamenopause (Kuntjoro, 2000). Hasil ini tidak sesuai dengan penelitian Marchira (2004) di Poliklinik Geriatri RS Dari Sardjito Yogyakarta, yang menyatakan bahwa dari 75 responden insomnia terdapat 40 $(53,3 \%)$ laki-laki lebih besar daripada wanita yaitu 35 responden $(46,7 \%)$. Adanya perbedaan hasil kemungkinan karena perbedaan metode, lokasi penelitian, dan karakteristik responden. Hal ini juga berbeda dengan penelitian yang dilakukan oleh Sonny (2003) menunjukkan bahwa laki-laki lebih banyak menderita insomnia yaitu sebesar $66 \%$ dari $100 \%$ populasi penelitian. Karena jenis kelamin responden yang digunakan lebih banyak laki-laki.

Menurut Dollander cit. Marchira (2004) kejadian insomnia lebih tinggi pada orang yang bercerai, berpisah, dan berstatus janda atau duda. Insomnia pada usia lanjut berhubungan dengan kematian pasangan. Hasil ini diperoleh karena subyek penelitian memang lebih banyak yang menikah. Menurut Maryam (2008) usia lanjut yang mempunyai pasangan hidup mempunyai tugas perkembangan yang harus dilakukan. Tugas perkembangan tersebut antara lain membina hubungan baik dengan pasangan, menjalin hubungan dengan sesama, dan siap untuk kehilangan pasangan. Apabila tugas perkembangan tidak dapat tercapai dengan baik dapat menimbulkan masalah psikologis. Masalah psikologis itu dapat memicu terjadinya insomnia.

Penelitian yang dilakukan Murti (2005) menunjukkan bahwa usia lanjut dengan pendidikan rendah yang menderita insomnia tiga kali lipat dari usia lanjut yang berpendidikan lebih tinggi. Hasil penelitian yang dilakukan Marchira (2004) menunjukkan bahwa usia lanjut yang menderita insomnia dengan pendidikan SD dua kali lipat dibandingkan usia lanjut yang tidak menderita insomnia, sedangkan usia lanjut yang mempunyai tingkat pendidikan lebih tinggi perbandingannya lebih kecil antara kelompok insomnia dan kelompok tidak insomnia. Respon terhadap stress setiap orang berbeda-beda karena mekanisme koping yang digunakan individu berbeda sesuai dengan kemampuan atau tingkat pendidikan. Individu dengan tingkat pendidikan yang tinggi menggunakan mekanisme koping yang adaptif dalam menghadapi stress (Rasmun, 2004).

Hasil penelitian mengenai efektifitas tehnik relaksasi progresif yang dilakukan setiap hari dengan dilakukan 3 kali seminggu menunjukkan hasil bahwa usia lanjut yang melakukan relaksasi progresif setiap hari mengalami insomnia sebanyak 3 orang $(23,08 \%)$ dan tidak insomnia 10 orang (76,92 \%). Sedangkan usia lanjut yang melakukan relaksasi progresif 3 kali seminggu menunjukkan hasil mengalami insomnia sebanyak 8 orang $(61,54 \%)$ dan tidak insomnia sebanyak 5 orang $(38,46 \%)$. Hal ini menunjukkan adanya perbedaan yang signifikan antara terapi relaksasi progresif setiap hari dengan tehnik relaksasi progresif 3 kali seminggu dalam menyembuhkan insomnia. Hal tersebut sesuai dengan teori yang 
dikemukakan oleh Jacobson dalam Davis (1995) bahwa tehnik relaksasi progresif yang dilaksanakan 20-30 menit satu kali sehari secara teratur efektif dalam menyembuhkan insomnia. Namun, dari hasil uji statistik dengan uji Chi Square didapatkan nilai $\chi^{2}$ hitung $=2,521$ sedangkan harga $\chi^{2}$ tabel $=3,841$ dan $p_{\text {value }}=$ 0,112 pada derajat kebebasan (df) 1, pada taraf signifikansi 0,05 maka Ho diterima artinya tehnik relaksasi progresif tidak efektif untuk mengurangi insomnia pada usia lanjut di Posyandu usia lanjut desa Buntalan.

Adanya perbedaan yang signifikan antara tehnik relaksasi progresif yang dilakukan setiap hari dan dilakukan 3 kali seminggu, maka tehnik relaksasi progresif yang dilakukan setiap hari dapat digunakan sebagai alternatif dalam memberikan intervensi pada lansia khususnya bagi lansia yang mengalami gangguan tidur dan istirahat. Karena seperti kita ketahui bahwa lansia merupakan kelompok rawan karena kepekaan dan kerentanannya yang tinggi terhadap gangguan kesehatan sebagai akibat menurunnya fungsi, kekuatan fisik dan fungsi kognitif, sumber-sumber finansial yang tidak memadai, dan isolasi sosial (Friedman, 1998).

Berkurangnya kemampuan adaptasi lansia terhadap perubahan-perubahan merupakan hal yang normal terjadi pada lansia. Perubahan - perubahan ini bersamaan dengan perubahan fisik yang lain. Pada lansia, umumnya dorongan homeostatik untuk tidur lebih dulu menurun, baru diikuti oleh dorongan irama sirkandian untuk terjaga. Selain hal tersebut, ritmik sirkandian tidur-bangun lansia juga sering terganggu, jam biologik lebih pendek dan fase tidurnya lebih maju. Gangguan ritmik sirkandian tidur ini dapat berpengaruh terhadap kadar hormon yaitu terjadi penurunan sekresi hormon pertumbuhan, prolaktin, tiroid, dan melatonin. Hormon-hormon tersebut disekresikan pada saat tidur dalam terutama pada malam hari, sehingga penurunan kadar hormon ini akan menyebabkan lansia sulit untuk mempertahankan tidur.

Perubahan-perubahan yang terjadi pada lansia tersebut merupakan suatu hal yang normal. Tetapi kebutuhan tidur tidak hanya dilihat dari aspek kuantitas saja karena setiap orang kebutuhan untuk tidur itu berbeda. Kebutuhan ini menetap sampai batas lansia. Pada proses degenerasi yang terjadi pada lansia, waktu tidur efektif akan semakin berkurang. Sehingga tidak tercapai kualitas tidur yang adekuat dan akan menimbulkan berbagi macam keluhan tidur. Berkurangnya jumlah jam tidur tersebut tidak menjadi suatu masalah jika lansia itu sendiri merasakan kualitas tidur yang nyenyak karena dengan kualitas tidur yang bagus meskipun hanya dua jam itu dapat memulihkan fungsi tubuh dan otak (Prayitno, 2002).

Selain hal-hal di atas, insomnia pada lansia disebabkan juga oleh faktor biologis dan faktor psikis. Faktor biologis seperti adanya penyakit tertentu yang mengakibatkan seseorang tidak dapat tidur dengan baik. Faktor psikis bisa berupa kecemasan, stres psikologis, ketakutan dan ketegangan emosional (Lueckenotte, 1996). Ketika lansia mengalami stress (ketegangan emosional), maka beberapa otot akan mengalami ketegangan sehingga mengaktifkan saraf simpatis. Pada kondisi stress, secara fisiologis tubuh akan mengalami respon yang dinamakan respon fight or flight. Respon ini memerlukan energi yang cepat, sehingga hati melepaskan lebih banyak glukosa untuk menjadi bahan bakar otot, dan terjadi 
pula pelepasan hormon yang menstimulasi perubahan lemak dan protein menjadi gula. Metabolisme tubuh meningkat sebagai persiapan untuk pemakaian energi pada tindakan fisik. Kecepatan jantung, tekanan darah, dan kecepatan pernapasan meningkat, serta otot menjadi tegang. Pada saat yang sama aktifitas tertentu yang tidak diperlukan (seperti pencernaan) dihentikan. Sebagian besar perubahan fisiologis tersebut terjadi akibat aktivitas dua sistem neuroendokrin yang dikendalikan oleh hipotalamus yaitu sistem simpatis dan sistem kortek adrenal (Purba, 2000).

Aktifnya saraf simpatis membuat lansia tidak dapat santai atau rileks sehingga tidak dapat memunculkan rasa kantuk. Melalui latihan relaksasi usia lanjut dilatih untuk dapat memunculkan respon relaksasi sehingga dapat mencapai keadaan tenang. Respon relaksasi ini terjadi melalui penurunan bermakna dari kebutuhan zat oksigen oleh tubuh yang selanjutnya aliran darah akan lancar, neurotransmitter penenang akan dilepaskan, sistem saraf akan bekerja secara baik, otot-otot tubuh yang relaks menimbulkan perasaan tenang dan nyaman (Purwanto, 2007).

Kondisi rileks yang dirasakan tersebut dikarenakan latihan relaksasi dapat memberikan pemijatan halus pada berbagai kelenjar tubuh, menurunkan produksi kortisol dalam darah, mengembalikan pengeluaran hormon yang secukupnya sehingga memberi keseimbangan emosi dan ketenangan pikiran. Tehnik relaksasi progresif cukup efektif untuk memperpendek waktu dari mulai merebahkan hingga tertidur dan mudah memasuki tidur. Hal ini membuktikan bahwa relaksasi progresif yang dilakukan dapat membuat tubuh lebih rileks sehingga kesulitan mengawali tidur dapat diatasi dengan penatalaksanaan ini. Hal yang sama diperkuat oleh teori Jacobson dan Mentz (2003) bahwa tehnik relaksasi progresif memberi respon terhadap ketegangan, respon tersebut menyebabkan perubahan yang dapat mengontrol aktivitas sistem saraf otonom berupa pengurangan fungsi oksigen, frekuensi nafas, denyut nadi, ketegangan otot, tekanan darah, serta gelombang alfa dalam otak sehingga mudah untuk tidur.

Terjadinya penurunan insomnia usia lanjut sesudah latihan relaksasi progresif setiap hari didukung juga oleh teori bahwa latihan relaksasi yang dikombinasikan dengan latihan pernapasan yang terkontrol dan rangkaian kontraksi serta relaksasi kelompok otot, dapat menstimulasi respon relaksasi baik fisik maupun psikologis. Respon tersebut dikarenakan terangsangnya aktivitas sistem saraf otonom parasimpatis yang terletak di separuh bagian bawah pons dan di medulla sehingga mengakibatkan penurunan metabolisme tubuh, denyut nadi, tekanan darah, dan frekuensi pernapasan dan peningkatan sekresi serotonin. Perangsangan pada beberapa area dalam nukleus traktus solitarius, yang merupakan region sensorik medulla dan pons yang dilewati oleh sinyal sensorik viseral yang memasuki oleh otak melalui saraf-saraf vagus dan glosofaringeus, juga menimbulkan keadaan tidur (Guyton dan Hall, 1997).

Latihan relaksasi progresif yang dikombinasikan dengan tehnik pernapasan yang dilakukan secara sadar dan menggunakan diafragma, memungkinkan abdomen terangkat perlahan dan dada mengembang penuh. Tehnik pernapasan tersebut mampu memberikan pijatan pada jantung yang menguntungkan akibat naik turunnya diafragma, membuka sumbatan-sumbatan dan memperlancar aliran 
darah ke jantung serta meningkatkan aliran darah ke seluruh tubuh. Aliran darah yang meningkat juga dapat meningkatkan nutrien dan $\mathrm{O}_{2}$. Peningkatan $\mathrm{O}_{2}$ dalam otak akan merangsang peningkatan serotonin sehingga membuat tubuh menjadi tenang dan lebih mudah untuk tidur (Purwanto, 2007).

Pada saat bernapas dalam, menghirup $\mathrm{O}_{2}$ melalui hidung dan dada mengembang diafragma terangkat, diikuti ekspirasi secara perlahan melalui mulut sehingga $\mathrm{CO}_{2}$ keluar. Pemenuhan $\mathrm{O}_{2}$ untuk tubuh tercukupi, perfusi jaringan baik sehingga kerja organ dan metabolisme baik Sedangkan pada saat merelaksasikan otot, sebuah sel saraf mengeluarkan opiate peptides atau saripati kenikmatan ke seluruh tubuh sehingga yang dirasakan adalah rasa nikmat dan tubuh menjadi rileks (Purba, 2002).

Tehnik relaksasi dapat memunculkan keadaan tenang dan rileks dimana gelombang otak mulai melambat akhirnya membuat seseorang dapat beristirahat dan tertidur. Konsistensi dari tehnik relaksasi progresif setiap hari secara teratur ini membuktikan bahwa tehnik relaksasi progresif mempunyai hasil yang signifikan untuk menurunkan insomnia pada usia lanjut. Beberapa faktor yang mempengaruhi keberhasilan tehnik relaksasi progresif dalam menyembuhkan insomnia yaitu konsistensi melakukan tehnik relaksasi progresif, kondisi lansia yang sehat serta lingkungan yang tenang saat melakukan tehnik relaksasi progresif. Dari hasil penelitian terjadi penurunan jumlah responden yang mengalami insomnia pada tiap-tiap skor setelah terapi relaksasi progresif.

Hasil ini disebabkan tehnik relaksasi progresif merupakan salah satu terapi yang membantu lansia dalam mengatasi insomnia. Selain itu dengan tehnik relaksasi progresif usia lanjut dapat meningkatkan ekspresi perasaan negatif menjadi positif sehingga membantu usia lanjut mengubah pola hidup yang dapat mengganggu kualitas dan kuantitas tidur usia lanjut (Sani, 2003). Hal ini juga terbukti selama intervensi berlangsung usia lanjut merasakan kondisi yang nyaman, tenang, dan rileks.

\section{Simpulan}

\section{SIMPULAN DAN SARAN}

Berdasarkan hasil penelitian yang dilakukan di Posyandu usia lanjut desa Buntalan, peneliti dapat menarik simpulan bahwa tehnik relaksasi progresif yang dilakukan setiap hari lebih efektif untuk menurunkan insomnia dibandikan dengan tehnik relaksasi 3 kali seminggu. Berdasarkan hasil statistik Tehnik relaksasi progresif tidak efektif untuk mengurangi insomnia pada usia lanjut di Posyandu usia lanjut desa Buntalan dengan $\mathrm{p}=0,112(\mathrm{p}>0,05)$. Didapatkan nilai $\chi^{2}$ hitung $=$ 2,521 sedangkan harga $\chi^{2}$ tabel pada taraf signifikansi 0,05 adalah $=3,841$.

\section{Saran}

Dalam rangka pengembangan latihan relaksasi progresif sebagai psikoterapi, peneliti menyarankan untuk dilakukan penelitian lebih lanjut tentang pengaruh tehnik relaksasi progresif tehadap tingkat insomnia usia lanjut dengan desain yang berbeda. Penelitian yang serupa dapat juga dilakukan pada area penelitian yang berbeda, dan dilengkapi dengan pemeriksaan untuk mengetahui adanya gangguan jiwa dan demensia. 


\section{DAFTAR PUSTAKA}

Abrams, W.B.(1997). The Merck Manual of Geriatri jilid II; alih bahasa: Monica. Bina Rupa Aksara .Jakarta.

Friedman, M.M.1998. Keperawatan Keluarga Teori dan Praktik Edisi 3. Jakarta. Penerbit Buku Kedokteran EGC

Gallo, Joseph J.(1998). Buku Saku Gerontologi, alih bahasa: James Veldman, ed.2, EGC:Jakarta.

Guyton, A.C.(1997). Fisiologi Manusia dan Mekanisme Penyakit, alih bahasa:Irawati Setiawan, Edisi III, EGC:Jakarta.

Keliat, A.B.(1999). Penatalaksanaan Stress, EGC:Jakarta.

Kuntjoro, Z.S.(2002). Masalah Kesehatan Jiwa Lansia, http://www.epsikologi.com/usia.[accessed 19 November 2008]

Lanywati, E.(2001). Insomnia Gangguan Sulit Tidur, Penerbit Kanisius: Yogyakarta.

Liu,Xianchen, Uchiyama. (2000). Sleep Loss and Day Time Sleepiness in the General adult Population of Japan Psychiatric research 93 .http://www.medicalzone.org.[accessed 19 November 2008]

Lueckenotte, A.G. 1996. Gerontological Nursing. Philadelphia. Mosby Year Book

Marchira, C.R.(2004). Hubungan Dukungan Sosial Dengan Insomnia Pada Lansia di Poli Geriatri RS Dr. Sardjito Yogyakarta. Tesis, Bagian Ilmu kedokteran Jiwa Fakultas Kedokteran UGM, Yogyakarta. Tidak dipublikasikan.

Mass, J.B.(2012). Power Sleep; alih bahasa:Kaifa: Jakarta.

Mentz. 2003. Relaxation Therapy. http//www.mayday.coh.org [diakses 2 Juli 2009]

Murti, D.S.(2005). Kecenderungan Strategi Koping Yang Digunakan Usia Lanjut Dalam Mengatasi Insomnia di Dusun Kerjo II Wilayah Kerja Puskesmas Ponjong I Gunung Kidul. Skripsi:UGM. Tidak dipublikasikan.

Nurmiati, (2007). Terapi Stress, http://www.kalbe.co.id/cdk.html [accessed 19 November 2008]

Panteri. I.G.P.(1993). Gangguan Tidur Insomnia dan Terapinya, Suatu Kajian Pustaka, Majalah Ilmiah th XX No 37.

Prayitno, A.(2002). Gangguan Pola tidur pada Kelompok Usia Lanjut, Jurnal Kedokteran Trisakti, Januari, vol.21, No.1.

Purba. 2002. Kardiovaskular dan Faal Olahraga. Bandung. Balai Penerbit Fakultas Kedokteran Universitas Padjadjaran

Purwanto, S \& Zulaekha, S.(2007). Pengaruh Pelatihan Tehnik Relaksasi Religius Untuk Mengurangi Gangguan Insomnia. Skripsi: UMS. Tidak dipublikasikan.

Rasmun. (2004). Stress, Koping dan Adaptasi Teori dan pohon masalah keperawatan, edisi pertama, Sagung Seto:Jakarta.

Stuart, G, Sundeen, S.J.(1998). Keperawatan Jiwa Buku Saku, alih bahasa:Monika, edisi III, EGC:Jakarta. 
Avicenna Journal of Health Research. Vol 2 No 2. Oktober 2019 (34-45)

Sugiyono, (2009). Metode Penelitian Kuantitatif Kualitatf dan $R \& D$, Alfabeta:Bandung.

Wahjudi, Nugroho.(2008). Keperawatan Gerontik dan Geriatri, editor: Monica Ester, ed 3, EGC:Jakarta.

Watson, R.(2003). Perawatan Pada Lansia. alih bahasa:Musri, EGC:Jakarta. 